\title{
EFFICACY OF MAXWIRE® ALLOY FILE IN REMOVING THE REMAINS OF ROOT CANAL FILLING MATERIAL IN VITRO
}

\author{
Martin Hashemi ${ }^{1}$, Miglè Mackevičiūtė ${ }^{2}$ \\ ${ }^{l}$ Folktandvården Skåne, Sweden \\ ${ }^{2}$ Lithuanian University of Health Sciences, Faculty of Odontology, \\ Department of Dental and Oral Pathology, Lithuania
}

Key words: retreatment, D-race, XP-endo Finisher R.

\begin{abstract}
Summary
Today it is more and more preferred to preserve teeth with promising prognosis rather than to extract them. The efficiency and the precision of retreatment files to remove filling material are important factors of successful treatment. The aim of this study was to evaluate the efficiency of MaxWire ${ }^{\circledR}$ alloy file in removing root canal filling material after retreatment with endodontic retreatment instruments. Distal roots of twenty human mandibular molars with single and straight canals were selected for this study. All canals were instrumented up to \#40/.04 with Bio-race system and apical preparation was finished with Kfile \#50/.02. Obturation was performed using lateral condensation technique with ADSEAL sealer. Radiographs were performed in buccolingual and mesiodistal directions with periapical X-ray after obuturation. Teeth were randomly divided into two groups with ten teeth in each. Group 1: removal of root canal filling material was performed using D-race system. Group 2: removal of root canal filling material was performed using D-race system following XP endo Finisher R instrument. Radiographs were performed after retreatment. Residual material was calculated in percentage left in canals. Statistical significance between the two groups were analyzed with t-test. Remnants of root canal filling material was observed in both groups: $38.90 \%$ in Group 1 and $13.71 \%$ in Group 2, respectively. There was a significant difference between the groups in term of the total root canal filling material $(p<0.05)$. MaxWire ${ }^{\circledR}$ alloy file significantly increased the amount of removed root canal filling material after retreatment with endodontic retreatment instruments.
\end{abstract}

\section{Introduction}

Retreatment in endodontics includes complete removal of root canal filling materials, disinfect, re-establish working length and re-obuturate the root canal $[1,2]$. The efficiency and the precision of retreatment files to remove filling material are important factors of successful treatment. The biggest challenge for these retreatment instruments is to follow the canal anatomy precisely enough in order to remove all root canal filling material. Improvements of the retreatment files suggest that the new XP-endo ${ }^{\circledR}$ Finisher R files remove more precisely and effectively than older ones [3].

New retreatment instrument made from NiTi MaxWire ${ }^{\circledR}$ material, XP-endo Finisher R (FKG Dentaire, La Chauxde-Fonds, Switzerland), offers higher flexibility and reaches areas of the canal walls impossible to reach with traditional and older files. It offers better access and cleaning properties due to very good resistance to instrument fatigue due to its zero taper $\# 30 / .0$ and the ability of the file to work in mixed phases which are exclusive for FKG MaxWire ${ }^{\circledR}$ alloys (martensitic-phase of $20^{\circ} \mathrm{C}$ and austentic-phase of $35^{\circ} \mathrm{C}$ ). Adaptation to canal morphology and preservation of the dentine. XP-endo Finisher R (FKG Dentaire, La Chauxde-Fonds, Switzerland) is only one file and has according manufacturer unique characteristics as: mechanical cleaning of the canal in areas previously impossible to reach due to its incredible flexibility. Thorough removal of residual obturation material during retreatment. This promises better and more reliable results in retreatment procedures [4]. Because of new XP-endo Finisher R's (FKG Dentaire, La Chaux-de-Fonds, Switzerland) promising functions it was chosen for the study.

The aim of this research was to evaluate the efficiency of MaxWire ${ }^{\circledR}$ alloy file in removing root canal filling material after retreatment with endodontic retreatment instruments. 


\section{Materials and methods}

Distal roots of twenty human mandibular molars with single and straight canals were selected for this research. Only teeth with minimal restorations or caries lesions and non-fused, well-developed roots were chosen for the presented research.

Preparation and filling of root canals. The research was carried out using 20 extracted human mandibular molars. Standard access cavities were prepared and the canal orifices were located. Teeth with single and straight distal canals were selected for this research. Bucco-lingual X-rays were performed using (EasyDent V4 Viewer, software Version 4.1.3.2, by VATECH, New York, USA). A silicone mold was made in order to hold the teeth in a correct and repeatable position.

Apical patency was confirmed and working length was established $1 \mathrm{~mm}$ shorter than the length at which a K-file \#10/.02 (MANI INC., Utsunomiya, Tochigi, Japan) was visualized at the apical foramen.

The initial root canal preparation was performed using BioRace system (FKG Dentaire, La Chaux-de-Fonds, Switzerland) according to manufacturers recomendations. Speed of 600rpm and $1 \mathrm{Ncm}$ torque was used with X-smart motor (Dentsply Maillefer, Ballaigues, Switzerland).

Apical preparation was performed with K-file \#50/.02 according to "morphometric and anatomical studies of the root canal system" [15]. During instrumentation canals were irrigated with $2 \mathrm{ml}$ of $5,25 \%$ sodium hypochlorite $(\mathrm{NaOCl})$ solution after each instrument and recapitulated with \#15/02. Following instrumentation, the smear layer of each canal was removed by applying $5 \mathrm{ml}$ of $17 \%$ ethylenediaminetetraacetic acid (EDTA) for 3 minutes, followed by rinsing with $10 \mathrm{ml}$ distilled water and then dried with paper points. The canals were obturated with gutta-percha and resin-based root canal sealer (ADSEAL, META BIOMED CO., LTD., Cheongju-si, Chungbuk, Korea) using lateral condensation technique. Zinc oxide eugenol was placed as a temporary filling.

Teeth were radiographed after obturation from two directions (mesiodistal and buccolingual) to check the quality of obturation at a fixed distance of $5 \mathrm{~cm}$. Teeth were stored in $100 \%$ humidity at $37{ }^{\circ} \mathrm{C}$ for 14 days to allow the sealer to set. After incubation period the teeth were randomly divided into two groups, 10 teeth in each.

Root canal retreatment. Group 1. D-race (FKG Dentaire, La Chaux-de-Fonds, Switzerland) was used as follows:

a drop of solvent was applied, Eucalyptus oil (PPH CERKAMED, Stalowa Wola, Poland) for $1 \mathrm{~min}$ followed by initial penetration with DR1 \#30/.1 with 1000rpm speed and $1.5 \mathrm{Ncm}$ torque to about $1-2 \mathrm{~mm}$.

DR2 was inserted into the canal with 600rpm speed and $1 \mathrm{Ncm}$ torque. The instrument was not forced inside, but rat- her was let to work inside the canal with slight pressure. The blade was regularly retracted and cleaned until full working length was reached. Retreatment was considered finished when there was no root canal filling material exiting the canal anymore after instrumentation [18].

Each instrument was discarded after one use to avoid instrument separations. Root canals were irrigated with $2 \mathrm{ml}$ of $5,25 \%$ sodium hypochlorite $(\mathrm{NaOCl})$ solution each time the instrument was retracted and the orifice was cleaned from all root canal filling material with gauze.

Group 2. The procedure described previously (Group 1) was performed. Then XP-endo Finisher R (FKG Dentaire, La Chaux-de-Fonds, Switzerland) was used as follows: the instrument was cooled and working length was measured. Access cavity was filled with solvent. Instrument was inserted into the canal to full forking length and was let to work for 30 seconds, then retracted and cleaned (also the orifice was cleaned with gauze). Second time access cavity was irrigated $2 \mathrm{ml}$ with $5,25 \%$ sodium hypochlorite $(\mathrm{NaOCl})$ solution and access cavity was filled with irrigant, instrument was again inserted to full working length and let to work for 30 seconds. Procedure was again repeated, instrument was retracted and cleaned and so was the orifice. Last step was done by filling access cavity with $17 \%$ ethylenediaminetetraacetic acid (EDTA), instrument was inserted again to full working length and let to work for 15 seconds. Retreatment was finished by rinsing with $10 \mathrm{ml}$ distilled water and then dried with paper points [19].

Each instrument was discarded after single use to avoid instrument separations.

Radiographic evaluation. After removal of the root canal filling material, each tooth was radiographed from mesiodistal and buccolingual direction at a fixed distance of $5 \mathrm{~cm}$ using the same silicone mold as mentioned earlier. Each radiograph was very closely evaluated with the obturated version and retreated version of same tooth to find common anatomical landmarks. Each radiograph was then divided into three parts (cervical, middle and apical), based on the common anatomical landmarks, with software Paint (Version 1607 (OSBuild 14393.693), Microsoft Windows). The procedure was repeated on all radiographs.

In order to calculate the percentage of remaining root canal filling material inside root canals all pictures were measured in square pixels with software Paint (to confirm identical size of pictures). The area of root canal filling material was calculated using Sketchandcalc software [20].

The areas of each third were identified through the difference in radiopacity, outlined and measured with the software. Then the areas of remaining root canal filling material in each third were identified, outlined and measured. 
Total canal areas and corresponding remaining filling material areas were calculated by adding the values obtained from the three thirds.

The area percentages of remaining filling material were calculated by dividing the filling material covered areas to the designated canal areas and multiplying by 100 (Fig. 1).

Statistical analysis. For the statistical analysis t-tests were performed with a significance level set at $5 \%$, by same operator as the experimental part using Social Science Statistics software [21]. The mean and standard deviation was calculated with Advanced Scientific Calculator software [22].

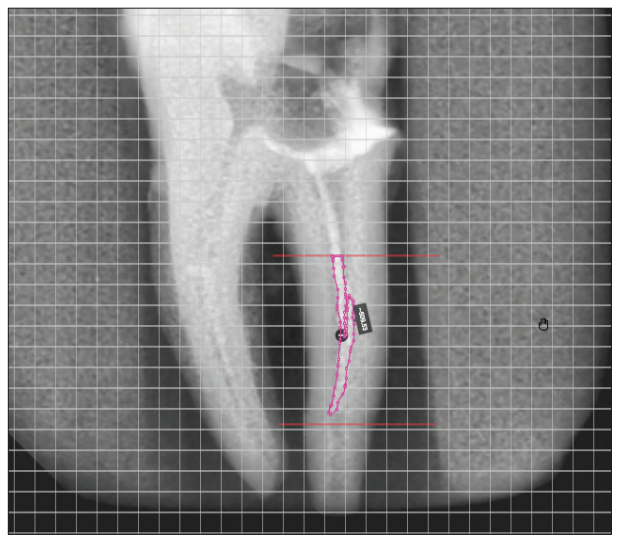

Fig. 1. Calculation of remnants of root canal filling material.

Table 1. Shown from each X-ray direction and each part how much root canal filling material remnants were left in canals.

\begin{tabular}{|l|c|c|c|c|}
\hline & \multicolumn{2}{|l|}{ D-race } & D-race + & $\begin{array}{c}\text { XP-endo } \\
\text { Finisher R. }\end{array}$ \\
\hline & $\begin{array}{c}\text { Bucco- } \\
\text { lingual }\end{array}$ & $\begin{array}{c}\text { Mesio- } \\
\text { distal }\end{array}$ & $\begin{array}{c}\text { Bucco- } \\
\text { lingual }\end{array}$ & $\begin{array}{c}\text { Mesio- } \\
\text { distal }\end{array}$ \\
\hline Cervical & $47.95 \%$ & $35.48 \%$ & $24.77 \%$ & $16.79 \%$ \\
\hline Medial & $37.90 \%$ & $32.34 \%$ & $13.01 \%$ & $10.81 \%$ \\
\hline Apical & $36.73 \%$ & $43.02 \%$ & $11.13 \%$ & $5.75 \%$ \\
\hline Total & $38.90 \%$ & & $13.71 \%$ & \\
\hline
\end{tabular}

Table 2. Area of residual filling material (means $+/$ - standard deviations (SD)) of each third of canal after instrumentation. In each column values followed by the same capital letters represent statistically significant $(\mathrm{p}<0.05)$ differences between the two groups.

\begin{tabular}{|l|c|c|c|c|}
\hline & Cervical & Medial & Apical & Total \\
\hline D-race & $41.7 \%$ & $35.1 \%$ & $39.9 \%$ & $38.9 \%$ \\
& $(19.9)^{\mathrm{A}}$ & $(22.6)^{\mathrm{A}}$ & $(29.6)^{\mathrm{A}}$ & $(24.1)^{\mathrm{A}}$ \\
\hline D-race + & $20.8 \%$ & $11.9 \%$ & $8.4 \%$ & $13.7 \%$ \\
XP-endo & $(17.8)^{\mathrm{A}}$ & $(18.1)^{\mathrm{A}}$ & $(16.2)^{\mathrm{A}}$ & $(17.9)^{\mathrm{A}}$ \\
Finisher R & & & & \\
\hline
\end{tabular}

\section{Results}

All teeth had significant amount of root canal filling material remnants, better results were observed in Group 2 , significant difference. The differences were checked for each part (cervical, middle and apical) and for each X-ray in percentage and in statistical significance (Table 1,2). In

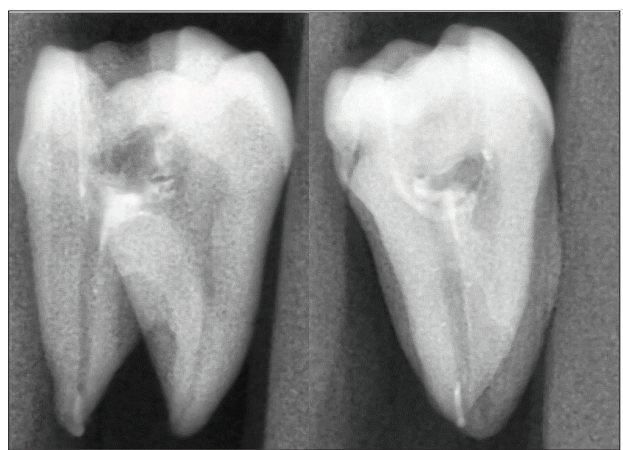

Fig. 2-a. Post-retreatment by group 1. "Good".

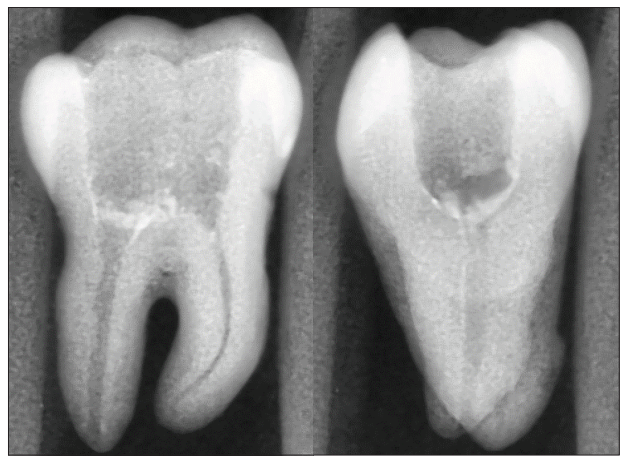

Fig. 2-b. Post-retreatment by group 1. "Poor".

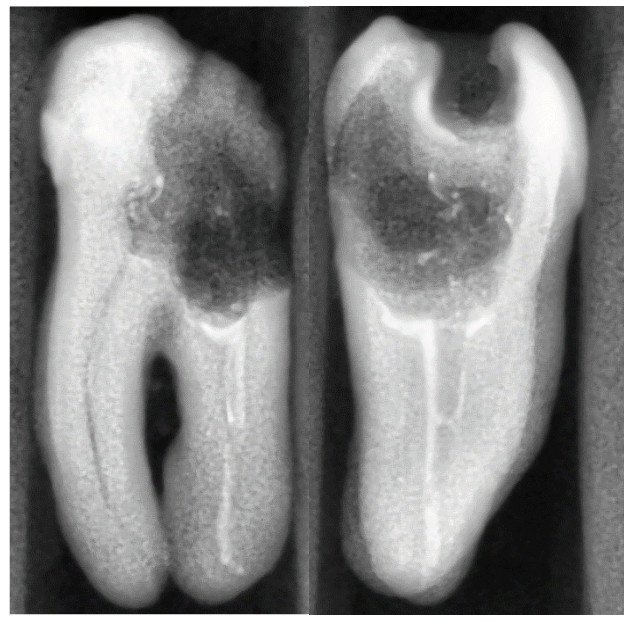

Fig. 2-c. Post-retreatment by group 2. "A normal case". 
Table 1 there is shown how much remnants were observed between these two systems. The use of XP-endo Finisher R showed a significant difference in cleaning ability in every part (cervical, middle and apical) and increased cleaning ability $(25.19 \%)$ (Table 1$)$.

Also the statistical significance between the two groups in each part of the canals were also recorded, as well as in total (Table 2). In the second group with XP-endo Finisher $\mathrm{R}$ there is a noticeable decrease of the standard deviation, showing its efficiency as a finishing file.

Representative radiographs for "good" cases with group 1 (Fig. 2-a) and "poor" cases with group 1 (Fig. 2-b), also a representative radiograph for a common case for group 2 (Fig. 2-c).

\section{Discussion}

The aim of this research was to evaluate the efficiency of MaxWire ${ }^{\circledR}$ alloy file in removing root canal filling material after retreatment with endodontic retreatment instruments, which is essential for good retreatment prognosis even though it has not been proven that it is a necessity to remove completely all old root canal filling material. It seems, however, essential to remove as much as possible in order to get to the infected parts that are hidden inside the canal [8].

This research was carried out with straight root canals and with minimal defects, therefore conclusions cannot be related to teeth with curved root canals or teeth with big defects, but can give a better understanding in general regarding endodontic retreatment. An important aspect needs to be addressed regarding the shape of the root canals: $30 \%$ of mandibular distal canals are "oval-shaped" $5 \mathrm{~mm}$ from apex [23], which may have had a big impact on our results - up 38.90\% material remnants. It was observed that D-race had not the same ability to follow the canal morphology, making a straight path towards the apex and not "scout" for remnants as XP-endo Finisher R. This instrument follow the morphology more precisely, due to its ability to work in mixed phases (martensitic-phase/austentic-phase), allows it to scout for remnants and become very flexible inside root canal. The results comparing to another study may vary depending on the canal morphology of the teeth used. Study conducted by Silva EJNL et al. (2015) used only oval-shape root canals and no statistical difference between WaveOne system and ProTaper Retreatment System [8]. Their results may have been different if the canals were only "non-oval" or mixed pool of canal types. In this research there were not paid any attention to the shape of the canals and the total pool was mixed.

There is a general trend showing apical preparations to be similar in different systems but better in middle and cervical parts if compared to D-race system in this research which may be because of many reasons $[10,11,24]$. Some of them may have been: use of solvent as eucalyptol-oil in all retreatment procedures which may dissolve gutta-percha inside the canal and cause it to stick to the canal walls and increments [24]. Also D-race system did not "scout" the morphology in search of root canal filling remnants but relies on an additional system/file to finish preparation.

The master apical file in the teeth used for this study was \#50 according to "morphometric and anatomical studies of the root canal system" [15]. This means that finishing with anything less than \#50 will mean almost $100 \%$ failure in removing $100 \%$ of root canal filling material in the apical part therefore the use of hand files (also any treatment files) are of still great use today for endodontic retreatments, especially Hedström files [25]. This shows why D-race in this study did not have as good efficiency as one might hope, even after discussing about solvents and not being enough flexible to follow anatomy to the apical part, it comes down mostly to the overall size of the file itself. It is impossible for a type of instrument as D-race to clean properly by itself because of its small size, however, the XP-endo Finisher R is made from a completely different technology which allows it to adapt and "scout" as previously mentioned the canal in search for root canal filling remnants, all thanks to its mixed phase technology which are exclusive for FKG MaxWire ${ }^{\circ}$ alloys (martensitic-phase of $20^{\circ} \mathrm{C}$ and austentic-phase of $35^{\circ} \mathrm{C}$ ).

The best is clearly to combine retreatment files in order to get the best possible retreatment. The XP-endo Finisher R was in a sufficient manner adding the effect of a second file, by removing a great part of the remaining root canal filling material by mechanical movement. Even in here a drop of solvent was used, but in this case because the file "explores the canal" and becomes extra flexible during treatment (initiated by heat) it most likely was helping with having softened gutta-percha.

The way of evaluation for success of retreatment, in this study, was by performing X-rays which were performed from 2 angles $90^{\circ}$ from each other. This should obtain a good overall picture of how much is left in canal and how much is removed in theory, but it would only work $100 \%$ in cases on a quadrat root with four corners in $90^{\circ}$. In this case, root canal anatomy in general is more rounded. It takes many different shapes which are not related to 90 degrees corners, this will cause a lot of clean areas to "hide behind" the gutta-percha filled wall. Ideally would be to use a three-dimensional visualization of the root to see all these "hidden" corners.

Another effect on the results regarding radiography may be due to different ways of dividing the canal thirds (cervical, 
middle and apical). Some researchers did not specify how they divided the root canal thirds $[9,11]$ while one divided strictly by thirds by the length (equal thirds) [8]. Comparing researchers with different methodology regarding radiography might also give some changes and different results not necessarily mean that any on them were wrong. In this study the canals were divided into thirds (cervical, middle and apical) according to identical anatomical landmarks (as close to equal thirds as possible). This will minimize any errors in X-ray angulation at the picture taking moment (because of the common anatomical landmarks, the area was kept the same).

Unfortunately, one last limitation to this research was that it was carried out in-vitro which can come very close to in-vivo researchers, but will never simulate $100 \%$ a clinical situation. This might have affected the results in all stages of this research (all necessary preventive measures were taken) even though they will be minimal they have to be acknowledged. Further study is definitely required, especially in-vivo.

\section{Conclusion}

Removing root canal filling material using D-race retreatment instruments were not efficient on its own, gross amount of radiopaque residue was evident in canals. Supplementary use of MaxWire ${ }^{\circledR}$ alloy file XP-endo Finisher R significantly reduced the amount of radiopaque residue.

\section{Acknowledgement}

The material support by FKG Dentaire (La Chaux-deFonds, Switzerland) for this study.

\section{Conflict of interests}

The author denies any conflict of interest related to this research.

\section{References}

1. Swetha K, Annapoorna Ballagere M. Efficacy of different methods for removing root canal filling material in retreatment - an in-vitro study. J Clin Diagn Res 2016; 10(6): ZC06-ZC10.

2. Sadia T, Farhan Raza K. Failure of endodontic treatment: The usual suspects. Eur J Dent 2016; 10(1): 144-147.

https://doi.org/10.4103/1305-7456.175682

3. FKG Dentaire SA expands its range of 3D instruments with the introduction of the XP-endo ${ }^{\circledR}$ Finisher R. La Chaux-de-Fonds. Press release May 2016.

4. FKG Dentaire SA. XP-endo Finisher 3D Generation. La Chauxde-Fonds, Switzerland [Brochure].

5. Rödig T, Hausdörfer T, Konietschke F, Dullin C, Hahn W, Hülsmann M. Efficacy of D-race and ProTaper Universal Retreatment NiTi instruments and hand files in removing gutta-percha from curved root canals - a micro-computed tomography study. Int Endod J 2012; 45(6):580-9.

https://doi.org/10.1111/j.1365-2591.2012.02014.x

6. Dhillon J, Bhagat A, Chhabra G. Efficacy of two rotary instruments for gutta percha removal during root canal retreatment. Bangladesh Journal of Dental Research \& Education 2014; 4(2), 56-60. https://doi.org/10.3329/bjdre.v4i2.20250

7. Dadresanfar B, Mehrvarzfar P, Saghiri MA, Ghafari S, Khalilak $Z$, Vatanpour M. Efficacy of two rotary systems in removing gutta-percha and sealer from the root canal walls. Iran Endod J 2011; 6(2): 69-73.

8. Silva EJ, Orlowsky NB, Herrera DR, Machado R, Krebs RL, Coutinho-Filho Tde S. Effectiveness of rotatory and reciprocating movements in root canal filling material removal. Braz Oral Res 2015; 29:1-6.

9. Preetam CS, Chandrashekhar M, Gunaranjan T, Kumar SK, Miskeen Sahib SA, Kumar MS. A comparative evaluation of two rotary Ni-Ti instruments in the removal of gutta-percha during retreatment. J Int Soc Prev Community Dent 2016; 6(Suppl 2):S131-6. https://doi.org/10.4103/2231-0762.189740

10. Madani ZS, Simdar N, Moudi E, Bijani A. CBCT evaluation of the root canal filling removal using D-race, protaper retreatment kit and hand files in curved canals. Iran Endod J 2015; 10(1): 69-74.

11. Abramovitz I, Relles-Bonar S, Baransi B, Kfir A. The effectiveness of a self-adjusting file to remove residual guttapercha after retreatment with rotary files. Int Endod J 2012; 45(4):386-92. https://doi.org/10.1111/j.1365-2591.2011.01988.x

12. Kerekes K, Tronstad L. Morphometric observations on root canals of human anterior teeth. J Endod 1977; 3(1):24-9. https://doi.org/10.1016/S0099-2399(77)80218-5

13. FKG Dentaire SA. Safe and efficient NiTi rotary system. La Chaux-de-Fonds, Switzerland 2012 [Brochure].

14. Kerekes K, Tronstad L. Morphometric observations on root canals of human premolars. J Endod 1977; 3(2):74-9. https://doi.org/10.1016/S0099-2399(77)80019-8

15. Kerekes K, Tronstad L. Morphometric observations on the root canals of human molars. J Endod 1977; 3(3):114-8. https://doi.org/10.1016/S0099-2399(77)80206-9

16. AlShwaimi E. Cyclic fatigue resistance of a novel rotary file manufactured using controlled memory Ni-Ti technology compared to a file made from M-wire file, 2018; 51(1):112-117.

17. Simsek N, Ahmetoglu F, Keles A, Bulut ET, Er K. 3D Analysis of D-race and self-adjusting file in removing filling materials from curved root canals instrumented and filled with different techniques. ScientificWorldJournal 2014; 2014:836513. https://doi.org/10.1155/2014/836513

18. FKG Dentaire SA. D-race: instructions for use. La Chaux-deFonds, Switzerland, 2015. 
19. FKG Dentaire SA. XP-endo ${ }^{\circledR}$ Finisher R: Instructions for use. La Chaux-de-Fonds, Switzerland, 2016.

20. Axiom Welldone (C). Area calculator sketch and calc [software]. 2014. Available from: https:/www.sketchandcalc.com/

21. Jeremy Stangroom (C). Social Science Statistics [software]. 2017. Available from: http://www.socscistatistics.com/Default. aspx

22. Giorgio Arcidiacono (C. Online scientific calculator [software]. 2009-2016. Available from: http://www.alcula.com/

23. Wu MK, R'oris A, Barkis D, Wesselink PR. Prevalence and extent of long oval canals in the apical third. Oral Surg Oral Med Oral Pathol Oral Radiol Endod 2000; 89(6):739-43.

https://doi.org/10.1067/moe.2000.106344

24. Akhavan H, Azdadi YK, Azimi S, Dadresanfar B, Ahmadi A. Comparing the efficacy of mtwo and D-race retreatment systems in removing residual gutta-percha and sealer in the root canal. Iran Endod J 2012; 7(3): 122-126.

25. Bueno CE, Delboni MG, de Araújo RA, Carrara HJ, Cunha RS. Effectiveness of rotary and hand files in gutta-percha and sealer removal using chloroform or chlorhexidine gel. Braz Dent J. 2006; 17(2):139-43.

https://doi.org/10.1590/S0103-64402006000200011

\section{MAXWIRE@ LYDINIO INSTRUMENTŲ EFEKTY- VUMAS ŠALINANT DANTIES ŠAKNIES KANALO UŽPILDO LIKUČIUS IN VITRO M.Hashemi, M.Mackevičiūtė}

Raktažodžiai: pergydymas, D-race, XP-endo Finisher R.
Santrauka

Pastaruoju metu stengiamasi išsaugoti vis daugiau net ir abejotinos prognozès dantų. Sẻkmingo gydymo svarbūs veiksniai yra pergydymo metu naudojamų instrumentų efektyvumas ir tikslumas. Šio tyrimo tikslas - jivertinti MaxWire ${ }^{\circledR}$ lydinio instrumentų efektyvumą šalinant danties šaknies kanalo užpildo likučius. İ studiją buvo įtrauktos apatinio žandikaulio krūminių dantų distalinès šaknys, turinčios vieną tiesų kanalą. Kanalai ruošti chemomechaniškai iki \#40/.04 Bio-race instrumentų sistema, viršūninė kanalo dalis baigta instrumentuoti K-tipo dildėmis \#50/.02. Dantų šaknų kanalai plombuoti lateralinès kondensacijos būdu naudojant Adseal silerị. Po plombavimo atliktos periapikalinès rentgeno nuotraukos skruosto-liežuvio ir artimaja-tolimaja kryptimis. Dantys atsitiktiniu būdu padalijami ị dvi grupes. 1 grupé: užpildas šalinamas Drace instrumentų sistema. 2 grupė: užpildas šalinamas D-race instrumentų sistema ir XP endo Finisher R instrumentu. Periapikalinès rentgeno nuotraukos pakartotos po užpildo šalinimo. Likusi užpildo dalis buvo apskaičiuota procentais. Statistinė priklausomybė tarp tiriamųjų grupių buvo apskaičiuota taikant t-testą. Užpildo likučiai buvo nustatyti abiejose grupèse: $38,90 \%$ - pirmojoje grupeje ir $13,71 \%$ antrojoje grupeje. Nustatyti statistiškai reikšmingi skirtumai tarp grupių $(\mathrm{p}<0.05)$. MaxWire ${ }^{\circledR}$ lydinio instrumentai padidina danties šaknies kanalo užpildo šalinimo efektyvumą atliekant endodontinš pergydymą.

Adresas susirašinėti: miglemackeviciute@gmail.com

Gauta 2018-03-21 